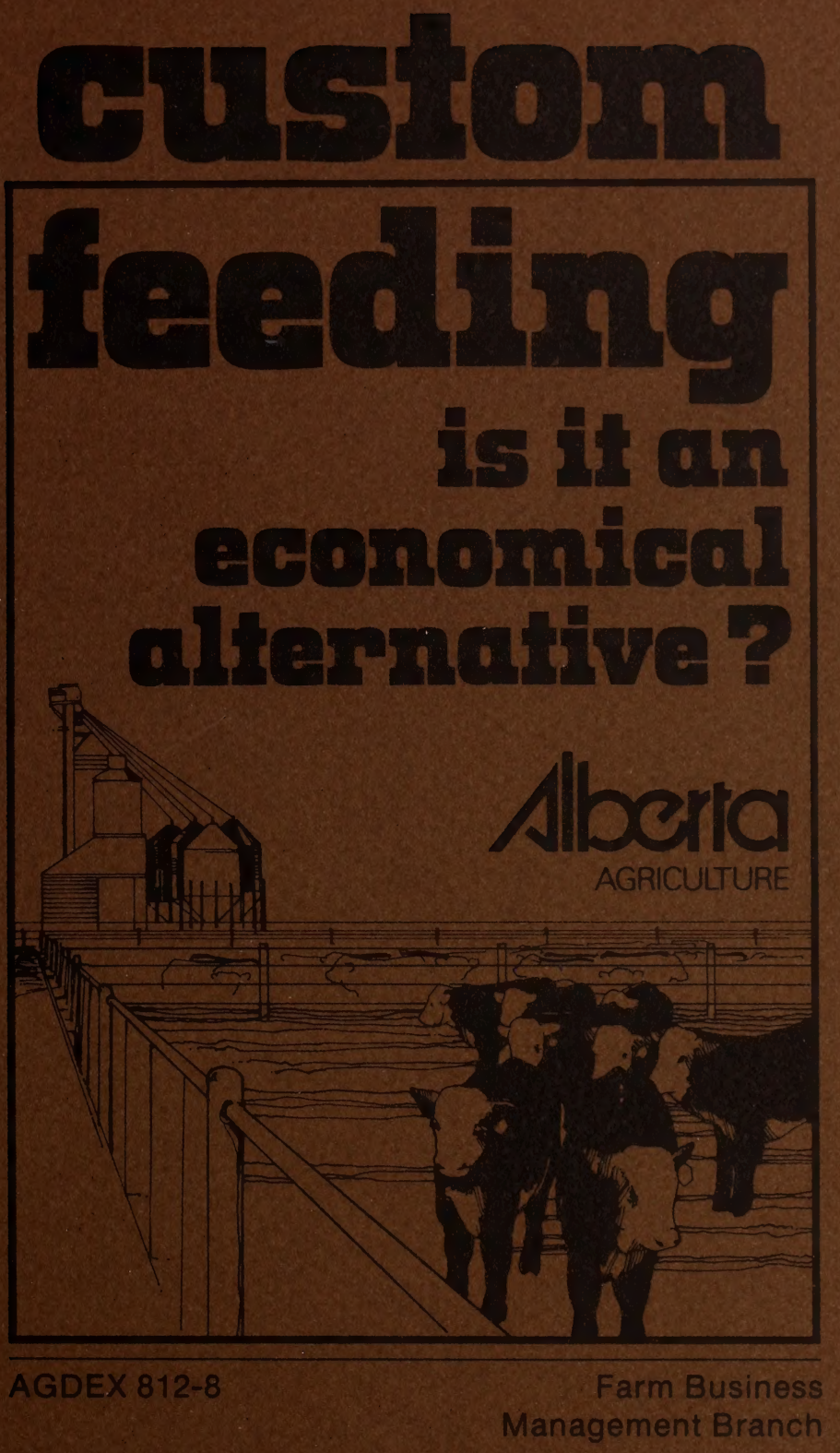

ODN

5534231 



\section{CUSTOM FEEDING:}

\section{Is It An Economical Alternative?}

AUGUST, 1984

Prepared By:

Peggy Johnson

FARM PLANNING SECTION

AGDEX 812-8

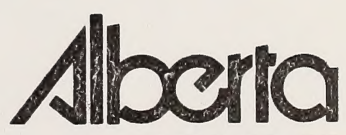

AGRICULTURE 



\section{PREFACE}

There has been a growing demand for information dealing with the economic feasibility of custom cattle feeding. Custom feeding can be an advantage to both the cattle owner and feedlot operator if a fair agreement is reached. Cattle prices are not expected to increase much in the immediate future while costs are likely to increase, resulting in narrow profit margins for the cattle owner and feedlot operator. Therefore, careful planning and use of budgets is imperative if an agreement is to be reached that will be fair and profitable to both parties.

This publication presents a summary of the factors to consider when evaluating a custom feedlot. It also provides two worksheets to be completed with your estimated costs in order to help decide whether to custom feed your cattle or feed them in your farm feedlot. It is also designed to help you decide which custom feedlot has the highest potential of providing you with a profit.

THE DEPARTMENT GRATEFULLY ACKNOWLEDGES THE CONTRIBUTION OF THE CUSTOM FEEDLOT OPERATORS WHO WILLINGLY CO-OPERATED BY PROVIDING INFORMATION ON CUSTOM FEEDLOT COSTS.

This publication was prepared by Peggy Johnson, Research Assistant, under the direction of Gerd Andres, Farm Planning Section, Farm Business Management Branch, Alberta Agriculture, Olds.

J. Wilson Loree, P.Ag., Head

Farm Business Management Branch

Box 2000

Olds, Alberta TOM IPO

August, 1984 
Digitized by the Internet Archive in 2016 


\section{TABLE OF CONTENTS}

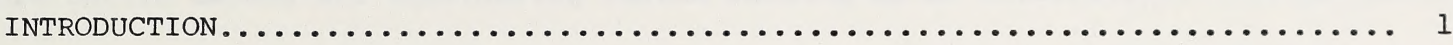

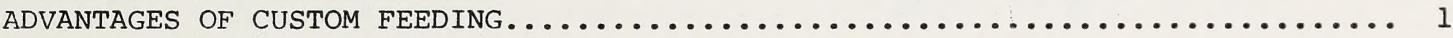

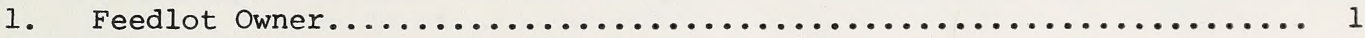

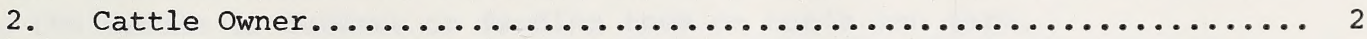

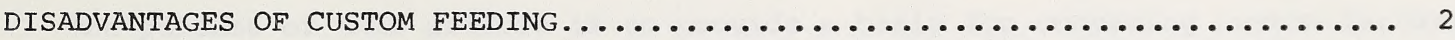

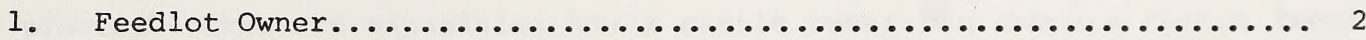

2. Cattle Owner...................................... 3

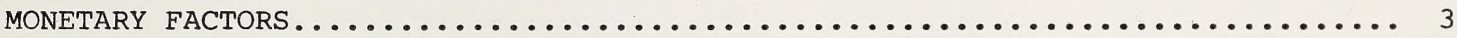

1. Purchase Price of the Feeder.......................... 4

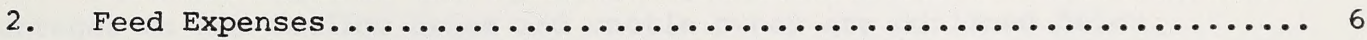

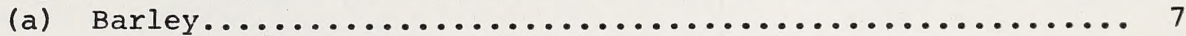

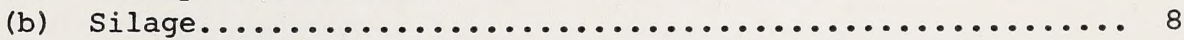

(c) Other Ration Ingredients........................ 8

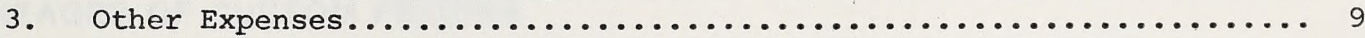

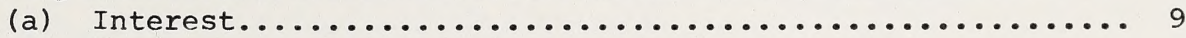

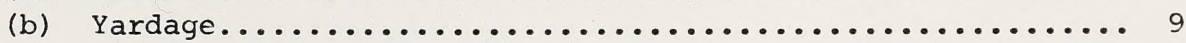

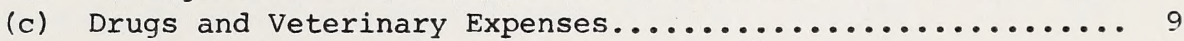

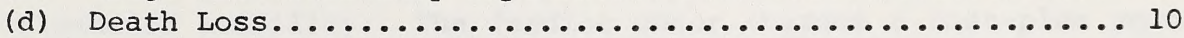

4. Total Expenses..................................... 10

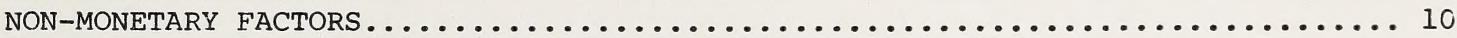

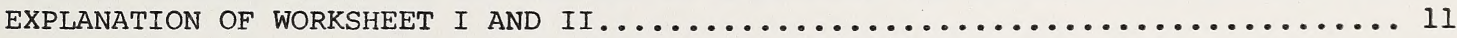

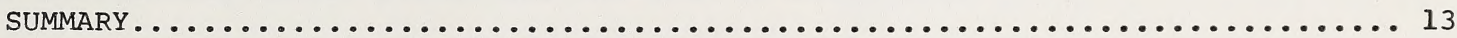

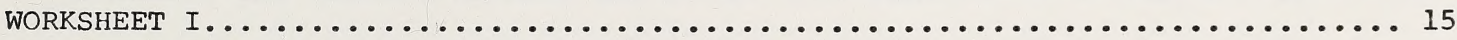

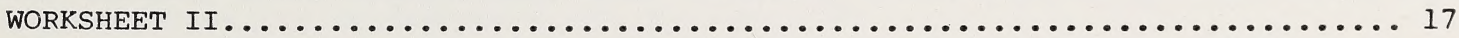

APPENDIX I - Government Publications

APPENDIX II - Questions? Please call us 


\section{CUSTOM FEEDING : IS IT AN ECONOMICAL ALTERNATIVE?}

Cattle feeding is a high risk enterprise. Some cattle owners feel that having their cattle custom fed provides them with a greater return, and for this reason more cattle owners are considering custom feeding as an alternative. Custom feeding is the practice of putting cattle in a feedlot operated by another individual (or company) and paying them for backgrounding or finishing the cattle, rather than selling the cattle as feeders or feeding them on one's own farm.

The purpose of this article is to provide a basis for comparing custom feedlots and to provide worksheets explaining how a cattle owner can compare custom feeding to feeding cattle on his/her farm.

There are many sound reasons for custom feeding. The advantages and disadvantages to the feedlot owner and cattle owner are outlined below.

\section{ADVANTAGES OF CUSTOM FEEDING}

FEEDLOT OWNER

- Increased financial stability: The feedlot owner charges a cost-plus amount for feed, yardage, drugs and bedding. These fees include a profit margin for the feedlot, thereby assuring the feedlot of a profit. The cattle owner assumes the risk of fluctuating market prices and the risk of death loss.

- Allows the feedlot to make use of its own supplies of forage and grain rather than selling these commodities, thus avoiding transportation and marketing costs for these commodities.

- Custom feeding allows feedlot owners to use their feedlot and storage facilities without the capital investment required for them to purchase cattle.

- Economy of scale--because of the high investment cost of a feedlot, the feedlot owner is able to spread total fixed costs over a larger number of cattle 
resulting in a decrease in fixed costs (investment cost, depreciation, insurance) per head. Price discounts for volume purchasing of minerals, feed additives, drugs and growth promoters are available. A price advantage may result when large numbers of cattle are sold. Large feedlots may benefit from more specialized management.

\section{CATTLE OWNER}

- By buying or keeping feeders in the fall and selling them in the spring of the new tax year, taxable income is deferred.

- Flexibility is added to ranch operations by allowing producers to retain ownership of their cattle when a higher market price is anticipated.

- The rancher does not have the fixed investment in facilities so he can choose to feed out his calves in only those years when it appears to be a profitable alternative.

- When feed supplies, labor or facilities are inadequate, the cattle owner can feed out replacemert heifers or bulls in a custom feedlot and have them returned later to the breeding herd.

- The custom feealot may have more bargaining power with packing plants that may result in finished cattle bringing a higher selling price than if the cattle owner marketed them independently.

\section{DISADVANTAGES OF CUSTOM FEEDING}

\section{FEEDLOT OWNER}

- The feedlot owner has little control over the condition of cattle received. They may have been havled long distances in bad weather or be under stress for other reasons. Cattle suffering from stress have a higher probability of getting sick or dying, even under top feedlot management. Similarly, off-type cattle, poor-doers and bred heifers that were supposed to be open increase feed and labor requirements and drag down the feedlot's performance. 
- The feedlot owner may experience some difficulty collecting payment for board and care of the cattle from the owner. However, the feedlot owner is protected by The Livery Stable Keepers Act which apparently supersedes The Bank Act. That is, the feedlot owner has the first claim on the animal (or the money, if the animal is sold) before anyone else, including someone holding an existing lien, a chattel mortgage, a bill of sale or other charge or encumbrance, but must follow the exact procedure set out in The Livery Stable Keepers Act.

\section{CATTLE OWNER}

- The cattle owner forfeits direct control over feeding practices and management of the cattle but must bear the cost if an animal dies, as well as loss of potential income through inefficient feedlot management.

- Problems can develop in the relationship between the feedlot owner and the cattle owner if a disagreement occurs. It is advised that all agreements be in writing.

\section{MONETARY FACTORS}

The economics of beef production depend on costs and returns. Cattle prices are not expected to increase much in the immediate future yet costs are likely to continue escalating. The average producer has little influence on returns, so can best optimize net return by controlling costs. The two budget worksheets at the end of this article provide a basis for cattle owners to compare their own costs to those of a feedlot. The worksheets also provide a basis for determining which feedlot would be most profitable from the cattle owner's point of view.

For the purpose of this article, the expenses incurred when cattle are purchased and fed in a custom feedlot will be divided into three main categories.

- purchase price

- feed expenses

- other expenses 
The order in which these topics are discussed is based on their economic impact. The most significant decision is the purchase price paid for the feeder. If the farmer or rancher already owns feeder cattle, the decision to feed them out rather than sell them must be considered as an opportunity cost; that is, the owner has forfeited the opportunity of selling the cattle at market price.

\section{PURCHASE PRICE OF THE FEEDER}

If cattle are purchased to put in a custom feedlot, the purchase price the cattleman pays for feeders is a key factor. The lower the purchase price, the higher the potential to make a profit. In a detailed study of cattle feeding costs and returns over a period of 30 to 35 months, it was found that cattle bought with a profit in them went to market with a profit in two out of every three cases.* The simplest way to determine the price that can be paid for feeders is to calculate the break-even purchase price using estimated figures. The average cost of gain that you use should allow for increases in feed prices.

To determine the break-even purchase price for feeder cattle, the following formula can be used:

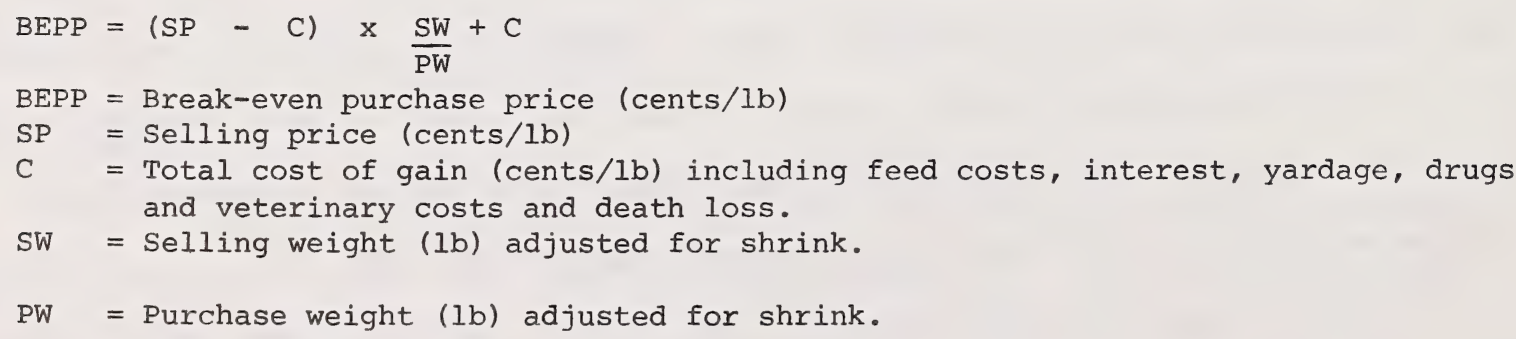


Example I shows how the purchase price can be calculated when feed costs and other costs are known.

\section{EXAMPLE I DETERMINING BREAK-EVEN PURCHASE PRICE}

Proposed feeding program: Type of feeders exotic cross sterrs Purchase weight $650 \mathrm{lb}$ Sale weight $1200 \mathrm{lb}$ Net gain $550 \mathrm{lb}(2.9 \mathrm{lb} / \mathrm{day}))^{\text {Time }}$ in feedlot $190+7=197^{*}$ days

FEED COSTS :

18.8 ibs feed $x+197$ days $x .8 .5$ $\$ 14.81$ (a)

OTHER COSTS :

(interest, yardage, drugs, death loss, etc.) $\$ 108.96$ (b)

TOTAL COST: $(a+b)$ $\$ 423.77$ (c)

Cost/1b. of gain: $\frac{\text { Total cost }}{\text { Gain }}=\frac{\$ 42.3 .7 .}{\ldots .5 .5 .0 \ldots}$ (c)

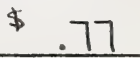

BREAK-EVEN PURCHASE PRICE:

$P P=(S P-C) \times \frac{S W}{P W}+C$

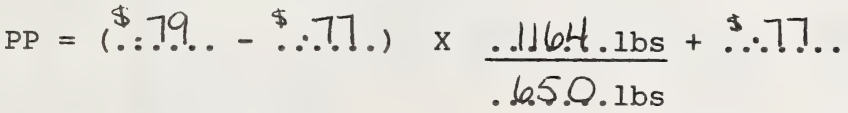

* (assume 3\% shrink, therefore 7 extra days are required to regain purchase weight). 


\section{FEED EXPENSES}

One of the most important variables influencing cattle feeding profit is cost of gain. Since feed costs usually represent $70 \%$ to $75 \%$ of the total cost of gain, a reduction in feed costs has a pronounced impact on cost of gain, as Example II shows.

Type of feeders Purchase weight

Exotic cross stesers

Net gain $550 \mathrm{lb}(2.9 \mathrm{lb} / \mathrm{day})$ Time in feedlot $190+7=197^{*}$ days sale price $79+11 \mathrm{~b}$

FEEDER COST:

Cost of feeder: 650 1bs. a $75^{\$} / 16=\$ 487.50$ /head FEED COSTS :

Case A Case B

18.8 lbs feed $x \perp 97$ days $x \underline{6.5} \quad 204.73$

18.8 lbs feed $x+197$ days $x \quad 8.5$ \& 14.81 OTHER COSTS :

(interest, yardage, drugs, death loss, etc.) $\quad 108.96 \quad 108.96$ TOTAL COSTS: (feeder, feed, other) $\quad 800.59 \quad 911.27$

EXPECTED PROFIT:

Gross return $=$ sale wt. 1164 lbs $\times$ c/1b $79 \quad \$ 919.56 \$ 919.56$ $\begin{aligned} \text { Profit/head } & =\text { gross return - total cost } \\ & =\$ 919.56 \quad \$ 800.59\end{aligned}$ $=\frac{919.56}{819.56}-\frac{800.59}{511.27}$

* (assume 3\% shrink, therefore 10 extra days are required to regain purchase weight). 
In Example II, the $2 \xi / 1 \mathrm{~b}$ difference in feed cost makes Case A fourteen times more profitable.

When analyzing the alternative of custom feeding cattle, the variability in feed prices charged by different feedlots is often confusing. The following table represents the variability in feed costs as shown in the custom rate survey carried out by Alberta Agriculture in June, 1984.

Table 1

FEED PRICES FROM SURVEY

\begin{tabular}{|lll|}
\hline & \multicolumn{1}{c|}{ Range } & Average \\
Barley & 5.0 to $7.12 \xi / 1 \mathrm{~b}$ & $5.84 \xi / 1 \mathrm{~b}$ \\
Milling & 15 to $43 \xi / \mathrm{bu}$ & $24.1 \xi / \mathrm{bu}$ \\
Silage & 1.15 to $3.5 \xi / 1 \mathrm{~b}$ & $1.76 \xi / 1 \mathrm{~b}$ \\
Minerals & 9 to $12 \xi / 1 \mathrm{~b}$ & $10.5 / 1 \mathrm{~b}$ \\
\hline
\end{tabular}

Barley

The variability in barley prices between feedlots can be explained by several factors: barley quality, moisture content, whether or not the milling cost is included in the barley price and the varying price mark-ups the custom feedlots charge.

Barley quality can vary a great deal. Average digestible energy content of Alberta grown barley is 1.66 megacalories (mcal) per pound on a dry-matter basis and average protein content is 12 per cent. Feedlot owners can assure their customers of top quality rations by balancing rations carefully and testing them on a regular basis at Alberta Agriculture's Soil and Feed Testing Laboratory or at private testing laboratories.

If the barley in feeder cattle rations is being paid for on a weightmeasurement basis, (i.e. cents per pound), comparison of prices should be made on a dry-matter basis of barley. Assuming nutrient quality of barley is equal, which alternative in the following example is the best feed for your money? 


\begin{tabular}{|c|c|c|c|c|c|c|}
\hline$\frac{\text { Percent }}{\text { Moisture }}$ & Barley & $\frac{\text { D Dry }}{\text { Matter }}$ & $\frac{\text { Price/ }}{\text { Pound }}$ & Calculation & & $\frac{\text { Price/ }}{\text { MCal }}$ \\
\hline $14 \%$ & diry & 868 & $5.35 \xi$ & $5.35 \% / 1 \mathrm{~b} \div(1.66 \mathrm{mcal} x$ & $.86 \mathrm{DM})$ & $3.748 \% / \mathrm{mc}$ \\
\hline $15 \%$ & tempered & $85 \%$ & $5.28 \xi$ & $5.28 c / 1 \mathrm{~b} \div(1.66 \mathrm{mcal} \times$ & $.85 \mathrm{DM})$ & $3.742 \xi / \mathrm{mcal}$ \\
\hline $25 \%$ & reconstituted & $75 \%$ & $5.21 \%$ & $5.21 c / 1 \mathrm{~b} \div(1.66 \mathrm{mcal} \times$ & $.75 \mathrm{DM})$ & $4.185 \mathrm{c} / \mathrm{mcal}$ \\
\hline $30 \%$ & high moisture & $70 \%$ & $5.00 €$ & $5.00 \% / 1 \mathrm{~b} \div(1.66 \mathrm{mcal} x$ & $.70 \mathrm{DM})$ & $4.303 \xi / \mathrm{mcal}$ \\
\hline
\end{tabular}

In Example II the high moisture barley costs the least per pound on an "as fed basis" but it is the most expensive when price per mcal is calculated. Given the above data the dry barley is the least expensive per mcal and, therefore, the best buy.

\section{Silage}

When silage costs are compared between different custom feedlots, variations also occur. As shown in Table 1, silage prices from the survey varied from $1.15 \%$ to 3.5६ per pound. These prices reflect "as fed" values. To find the best silage value for your money, a dry-matter calculation must be done similar to Example III. In order to do this calculation correctly, you must know the nutrient content, moisture content and the price of the silage.

Other Ration Ingredients

Minerals, supplements and feed additives are usually added to make balanced rations, and may be charged for separately or as part of the mark-up on barley or silage. When charged for separately these ingredients cost $9 \xi$ to $12 \xi / 1 b$, or about $7.5 \%$ of the total ration price.

An important way to decrease feed costs and increase profit is to improve feed efficiency. When comparing feed efficiency in different feedlots, it is necessary to compare two different pens of cattle. These cattle should be of similar breed, age and sex, should be fed in similax weather conditions and should be fed rations of similar mutrient density. 
OTHER EXPENSES

Interest

The cattle owner must also consider interest on the feeder and feed. In the farm feedlot budget example (Worksheet II) at the end of this article, interest is calculated on feeders and feed even if the farmer owns them. This interest is an opportunity cost rather than a cash cost. It is the amount of interest that could have been earned if the cattle and feed had been sold.

Buying large or top quality stock may cost more, and may result in a higher interest charge; however, this higher interest cost is offset by a shorter feeding period. When feed prices are high and feeder prices are low, it may be more feasible to purchase larger stock. The reverse of this situation also holds true. $\underline{\text { Yardage }}$

Yardage is the fee charged by the feedlot owner for the use of the feedlot facilities. Yardage in custom feedlots currently ranges from 0 to $20 \% /$ head / day with the most common fee being $13 \%$ to $16 \% /$ head/day. For the feedlot owner, this fee pays for feedlot maintenance, utilities and all or a portion of labor expenses, depending on the employee/animal ratio. Yardage may also include part of the interest expense that a feedlot has to pay.

\section{Drugs and Veterinary Expenses}

Drugs and veterinary expenses are charged to feedlot customers in many different ways. To reduce the amount of bookkeeping required, a daily rate, for example, 1c/head/day may be charged. The disadvantage of this system is that a pen of healthy cattle is charged the same amount as a pen of cattle with severaI sick animals requiring more care. More often processing fees are charged a standard amount on a per head basis (i.e. $\$ 7.50 /$ head) and drugs are charged at cost plus 10\% to $30 \%$. The system that requires the most bookkeeping is where each drug and each treatment is charged for separately; for example, vaccination $\$ 1$, branding $\$ 1$, 
castration $\$ 2$, dehorning $\$ 1$, implanting $\$ 2.85$, etc. According to the survey, the most commonly used system is the standard charge per head plus a $10 \%$ to $30 \%$ mark-up on drugs. In the example, a 108 mark-up is assumed.

Also, the manager of the feedlot you consider should have a complete knowledge of implants, Rumensin, MGA, warble control and wormers, and be willing to use them on your cattle.

\section{Death Loss}

The risk of death loss is usually assumed by the cattle owner. Death loss in the feedlots surveyed in 1984 varied from $0.75 \%$ to $2.25 \%$ for calves and from $0.5 \%$ to $0.8 \%$ for yeariings. When evaluating a custom feedlot, look for one that has a health program supervised by a consulting veterinarian. This will reduce the risk of death losses.

\section{TOTAL EXPENSES}

When all costs axe considered, a minimum total cost per pound of gain is desirable only if rates of gain are not sacrificed in order to reduce costs. Total cost/lb of gain in the feedlots surveyed ranged from 43 to $98 \% / 1 b$ with the most common price being $50 \xi$ to $65 \xi / 1 b$.

\section{NON-MONETARY FACTORS}

In addition to comparing prices of inputs, experienced cattle owners compare many other factors before choosing a custom feedlot. When they visit the feedlot some of the things they do are:

- Ask to see the five best, the five worst and five average close-out sheets for the last year. All lots have a few bad pens so this will give you a more realistic picture. Talk to present customers about their results. 
- Check out the status of the feedlot you plan to do business with. Watch for management and ownership changes. Your banker should be able to help you check out the financial stability of the lot.

- Check out the feedlot's ability to market your fat cattle. How many buyers can you expect to bid on your cattle? What is the feedlot's reputation for quality of finish? Will packers buy on the weights out of the feedlot? Is the feedlot large enough to have a marketing advantage? How far is the lot from packing plants?

- Assess the physical appearance of the feedlot with regard to pen space per head, adequate drainage, width of concrete in front of the feedbunk, protection from high winds, etc.

- Try to feed the kind of cattle the feedlot specializes in. About one-half of the feedlots surveyed did not specialize in either backgrounding or fattening, however, specializing may improve efficiency.

- Look for a feedlot owner-manager that you can talk to. Good communication between the cattle owner and the feedlot manager can only make for a better relationship.

- Performance guarantees can be found, but will usually cost the cattle owner more because guarantees take the risk off the cattle owner and place them on the feedlot.

Worksheets I and II can help you to compare the alternative of custom feeding cattle (Worksheet I) to feeding cattle on one's own farm (Worksheet II). Worksheet I can also be used when comparing different custom feedlots. By completing one copy of Worksheet I for each feedlot being considered, the feedlot with the greatest profit potential can be selected. Both worksheets are calculated on a per head basis. 
Although it is difficult to accurately determine all factors in a cattle feeding decision, it is still a useful exercise to estimate which alternative is more profitable. The example in Worksheet I and II compares the cost of custom feeding cattle at a feedlot with feeding the cattle out on one's own farm.

In both worksheets, the cost of a $650 \mathrm{lb}$ feeder is $75 \mathrm{c} / \mathrm{lb}$, resulting in a total value of $\$ 487.50$

In Worksheet I, the quantity and price of each ration were estimated by the cattle owner and the feedlot manager. Total feed expenses were estimated at $\$ 306.90$ per head in Worksheet I, while in Worksheet II the cattleman estimated total feed expenses would be $\$ 261.40$, which is $12 \%$ less than the custom feedlot feed expenses. This allows for the custom feedlot's 128 mark-up on feed used in this example. In both worksheets it was assumed that ration 1 was fed for 90 days and ration 2 was fed for 107 days. Since feed charges can vary from month-to-month, a small margin should be allowed for feed price fluctuations. In some instances a feedlot may quote an approximate total feed expense, thus eliminating the step-by-step feed calculation that is shown in the example.

Variable expenses in worksheet I and II amounted to $\$ 115.74$ and $\$ 156.60$ respectively. The yardage charge in the custom feedlot budget (Worksheet I) is comparable with the facilities, machinery and labor expenses that are charged in the farm feedlot budget (Worksheet II).

Drugs and veterinary expenses in Worksheet I are 10\% higher than in Worksheet II to allow for a $10 \%$ feedlot mark-up. Similarly, bedding in the custom feedlot budget is marked up by $12 \%$.

Farm feedlots are usually too small to attract enough buyers to assure the cattle owner of a competitive market price. Therefore, the finished cattle are shipped to a terminal market. The marketing expense in Worksheet II covers transportation expense to the terminal market as well as commission, yardage, 
Hartford insurance, brand inspection, Alberta Cattle Commission fees, etc.

Fixed expenses (investment cost, depreciation, insurance) appear on Worksheet II at a total cost of $\$ 15.77 /$ head. The increase in investment cost that has occurred over the past four years is taken into consideration by adding $20 \%$ to the investment cost shown in the 1980 Alberta Agriculture publication "A Consensus of Cost and Returns For a 200 Head Farm Feedlot, Olds District". Since the worksheets are calculated on a "per head" basis, the investment cost of $\$ 19,710$ is divided by 200 head of cattle. Although fixed expenses also occur on a custom feedlot, they do not appear on Worksheet I because they are paid through mark-ups on feed, bedding and drugs and occasionally through yardage.

Total expenses for Worksheet I and II are $\$ 910.14$ and $\$ 921.27$ respectively. This is the sum of the feeder cost, feed expenses and other expenses.

The budget sheet can also be used to calculate the break-even purchase price of feeders. If the total calculated expenses from Worksheet I and II are divided by the sale weight of the finished animal, the break-even purchase price is the result. In the example the break-even purchase price is $\$ 78.19 /$ cwt on Worksheet I and $\$ 79.15 /$ cwt on Worksheet II.

The expected profit can be calculated by subtracting the total expenses from the gross returns. In the example, Worksheet I shows a profit of $\$ 9.42 /$ head while Worksheet II shows a loss of $\$ 1.71 /$ head. The feeding situation used is unique and is only for illustration purposes. Given different costs and returns this result could be reversed. In order to make a proper analysis for your situation, you must use your own cost figures.

In order to compare the alternative of custom feeding cattle to feeding cattle in your own farm feedlot and to compare one custom feedlot with others, many 
variables need to be considered. However, since the average producer can have little influence on selling prices, the best way to optimize net returns is by controlling cost variables. The three cost variables that can influence profitability of cattle feeding the most are the price paid for feeders, feed expenses and other expenses as explained in more decail in the body of this article. Because these expenses are calculated in different ways from feedlot to feedlot, and from farm to farm, an equitable base has been developed so price comparison is possible between custom feedlots and between a custom feedlot and a farm feedlot. The equitable base that has been developed is in the form of the two budgeting worksheets. By completing a copy of Worksheet I with approximate estimates from each custom feedlot you are considering, it is possible to select the feedlot with the highest potential of making a profit. Also by completing a copy of Worksheet I with approximate estimates and comparing it to Worksheet II, which has been completed using your own farm feedlot costs, you can select the alternative which is most likely to yield a profit.

The worksheets show an example whereby a profit would be incurred if the cattle were kept in the custom feedlot and a loss would be suffered if they remained in the farmer's own feedlot. THIS IS AN EXAMPLE ONLY. The only way to select the most profitable alternative for your situation is to complete the worksheets using your cost figures. 
Type of feeders

Purchase weight

Exotic cross stęrs

$650 \mathrm{lb}$ sale weight

Net gain $550110(2.91 \mathrm{~b} / \mathrm{da} 4)$

Time in feed $\overline{10 t} 190+7=197$

sale price $794 / 16$

days.

A. COST OF FEEDER:

1050

Ibs. a $75^{4} / \mathrm{b}$

$=\$$

487.50

$\$ 487.50$

B. FEED EXPENSES:

Ration 1

Grain 24.25 bu. @ \$

Supplement

Hay

ib. e $\$$

Silage ton @ \$

Ration $\overline{2}$ ton (a) \$

Grain

Supplement

Hay .63

$\$$

$\frac{2.80}{-10} / 1 \mathrm{bu}$.

$=\$$
$=\$$
$=\$$
$=\$$

bu. a $\$$

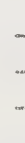
ton a $\$$

Silage ton

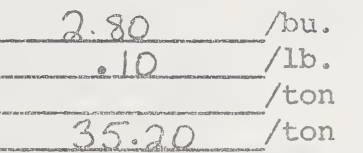

$=\$ \frac{117.60}{10.00}$
$=\$ \frac{10}{26.40}$
$=\$ \frac{1}{2}$

Pasture

Salt and Minerals days $\$ \$$ /day = \$

other

Rumsnsin

$\$ \frac{2.00}{4.00}$

Total feed expenses \$

$306.90 \$ 306.90$

C. OTHER VARIABLE EXPENSES:

Transpoxtation to feedlot

Yardage 197 days $x \quad 14$ \&/head/day

Drugs and veterinarian @ \$ 7.50 /head

Death Loss $1.5 \%$ × $\$ 487.50$ feeder cost

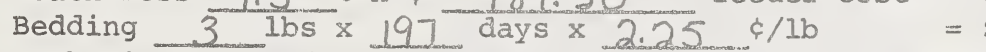

Marketing costs (transportation, commission, etc.)

Interest on feeders $\$ 487.50 \times 15 \% \times \frac{19 / 365}{4 x}$

Interest on feeding expense $\frac{\$ 306.90}{2} \times \frac{15 \%}{197 / 36.5}$ yr

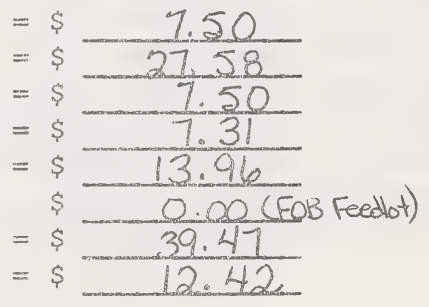

Total other expenses \$

D. TOTAL EXPENSE (feeder, feed, other) $(A+B+C$ )

$115 \cdot 74 \$$

115.74

-

E. EXPECTED PROFIT:

Sale wt. 1164 lbs. x expected sale price $\$ .79 \quad / 1 \mathrm{~b}=\$ 919.56$

Gross return $\$ 919.56$ - Total expenses $\$ 910.14=$ per head $\$ 9.42$

F. BREAK-EVEN SALE PRICE:
Total expense
$\$ 910.14$
$\div \quad$ sale weight less $3 \%$ shrink
$=\quad \operatorname{per} 1 \mathrm{~b} \cdot \$$

$\$ 910.14$

$19.14 \div-7164$

* (assume $3 \%$ shrink, therefore 7 extra days required to regain purchase weight). 


\section{WORKSHEET I CUSTOM CATTLE FEEDING BUDGET (PER HEAD)}

Type of feeders

Purchase weight

Net gain

Sale weight

Time in feedlot

A. COST OF FEEDER:

1.bs. @

$=\$$

$\$$

B. FEED EXPENSES:

Ration 1

Grain

bu. @ $\$$

Supplement

Hay

Silage

Ration 2

Grain

Supplement

Hay

Silage

1b.

ton a \$

ton a \$

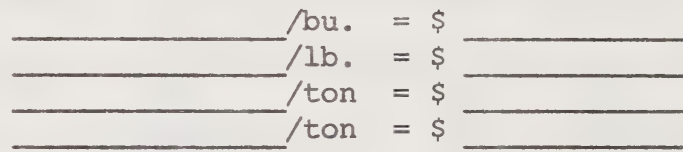

Pasture

Salt and Minerals

Other

bu. @ \$

1b. e \$

ton @ $\$$

ton a $\$$

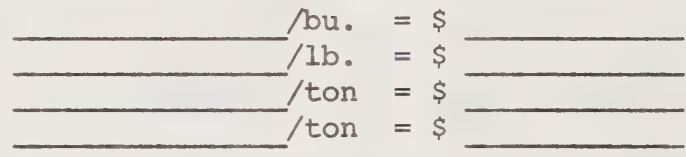

days $\$ \$$

/day $=\$$

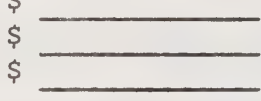

Total feed expenses $\$$

$\$$

C. OTHER VARIABLE EXPENSES:

Transportation to feedlot

Yardage days $\mathrm{x}$

Drugs and veterinarian @

Death Loss

\% $\mathrm{X} \$$

\&/head/day

Bedding Ibs $x$

Marketing costs (transportation,

Interest on feeders \$

Interest on feeding expense $\$$

$x$

commission, etc.) \$

head

feeder cost $=\$$

$\phi / 1 \mathrm{~b}=\$$

o 8 Xr $=\$$

$\mathrm{x}+\mathrm{yr}=\$$

Total other expenses \$

$\$$

D. TOTAL EXPENSE (feeder, feed, other) $(A+B+C)$

$\$$

E. EXPECTED PROFIT:

Sale wt.

lbs. $\mathrm{x}$ expected sale price $\$$

$/ 1 \mathrm{~b} .=\$$

Gross return \$

- Total expenses $\$$

$=$ per head $\$$

F. BREAK-EVEN SALE PRICE:

Total expense $\div$ sale weight less $3 \%$ shrink $=$ per $1 \mathrm{~b} . \$$

$\$$ 
Type of feeders exatic cross steres

Purchase weight $650 \mathrm{lb}$ Sale weight Net gain $550 \sqrt{\mathrm{b}(2.9 \mathrm{lb} / \text { day })}$ Time in feedlot

120016 190 days.

A. COST OF FEEDER: 650 ibs. @ $75^{\$} / 16 .=\$ 487.50 \$ 487.50$

B. FEED EXPENSES:

Ration 1

Grain 22.5 bu. a s

Supplement

Hay 90 1b. a \$

Silage

Ration $\overline{2}$ ton a \$

Grain

Supplement

Hay

Silage 59 ton a $\$$

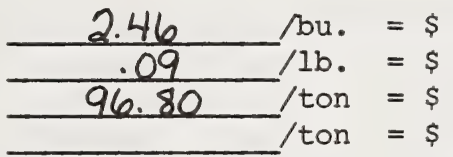

$\frac{\frac{55.35}{8.10}}{\frac{57.11}{5}}$

Pasture

Salt and Minerals

other

Rumensin

bu. @ \$

1b. e $\$$ ton e $\$$ ton a s

$2.46 / \mathrm{su}=\$$

103.32

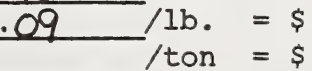

$30.98 /$ ton $=\$$

9.00

$\$$

days $\$ \$$

/day $=\$$

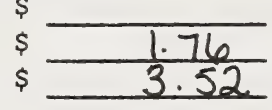

Total feed expenses \$

$261.40 \div 261.40$

C. OTHER VARIABLE EXPENSES:

Facilities expenses (utilities \& maintenance)

Machinery expenses (fuel, lubrication, repairs)

Drugs and veterinarian a $\$ \frac{6.75}{450}$

head

Death Loss $1.5 \%$ \% $\$ 47.50$

feeder cost

Bedding 3 1bs $\times 190$ days $x+1.98 \% / 1 \mathrm{~b}$

Marketing costs (transportation, commission, etc.)

Interest on feeders $\$ 487.50 \times 15 \% 190 / 365 y$

Interest on feeding expense $\$ 261.40 \times 10^{8} \times \frac{16965 \mathrm{yr}}{5.65}$

Labor

8 $\mathrm{hrs} / \mathrm{head} \times \$ 5.00 / \mathrm{hr}$

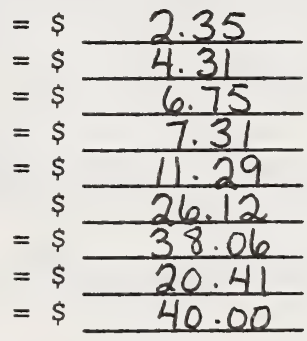

Total other expenses $\$ 156.60 \$ 156.60$

D. FIXED EXPENSES:

Interest on facilities \& machinery

$\frac{19,710}{\text { Depreciation on facilities }} \times \frac{1}{\text { \& machinery }}$ yrs. $\div 200$ head $=\$ \frac{14.78}{15 \%}$

$\frac{\$ .19,710 \ldots \times}{\ldots 10 . . \text { yrs }} \times \frac{200}{20} \div \frac{}{20 a d}$

Total fixed expenses $\quad=\$ 15.77$ \$

$=\$ .99$

$=\$ \frac{15.77}{\$ 15.77}$

E. TOTAL EXPENSE: (feeder, feed, variable \& fixed) $(A+B+C+D)$

$\$ 921.27$

F. EXPECTED PROFIT:

Sale wt. $\frac{1164}{16 s .} \times$ expected sale price $\$ \frac{.79}{921} / 1 \mathrm{~b} .=$
Gross return (F) $\$ 919.56$ - Total expenses (E) $\$ 921=$ per head

$11 b .=\$ 919.56$

G. BREAK-EVEN SALE PRICE:

Total expense $\div$ sale

$\$ 921.27$

sale weight less $3 \%$ shrink

1164

$=\quad$ per 1b. $\$ . .7915$ 
Type of feeders

Purchase weight

Net gain

Sale weight

Time in feedlot

days.

A. COST OF FEEDER:

1bs. @

$=\$$

$\$$

B. FEED EXPENSES:

\section{Ration 1}

Grain

bu. @ $\$$

Supplement

1b. a $\$$

Hay

Silage

ton a $\$$

Ration 2

Grain

ton e $\$$

Supplement

Hay

silage

bu. e $\$$

Ib. a $\$$

ton e $\$$

ton e $\$$

\begin{aligned}$/$ bu. & $=\$ \\$\hline$/ 1 \mathrm{~b} & .=\$\end{aligned}$

$/$ ton $=\$$

$/$ ton $=\$$

Pasture

days $\$ \$$

Salt and Minerals

Other

/bu. $=\$$

/1b. = $\$$

$/$ ton $=\$$

/ton $=\$$

$/$ day $=\$$

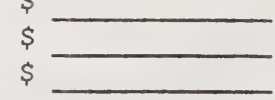

Total feed expenses $\$$ $\$$

C. OTHER VARIABLE EXPENSES:

Facilities expenses (utilities \& maintenance)

Machinery expenses (fuel, lubrication, repairs)

Drugs and veterinarian @ $\$$

Death Loss \& $\mathrm{x} \$$ head

Bedding lbs $x$ feeder cost

Marketing costs (transportation, commission, etc.)

Interest on feeders \$

Interest on feeding expense

Labor hrs/head $\times$ \$
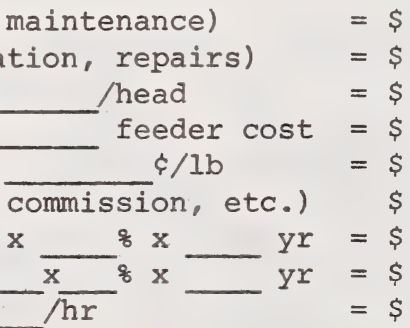

Total other expenses $\$$ $\$$

D. FIXED EXPENSES:

Interest on facilities \& machinery

$\$ \quad x \quad x$ yrs. $\quad x$

Depreciation on facilities \& machinery

$\$ \ldots . . . . . . \times x$ $\div$

$\ldots \ldots$ yrs

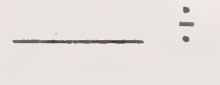

Total fixed expenses $=\$$ $\$$

E. TOTAL EXPENSE: (feeder, feed, variable \& fixed) $(A+B+C+D)$ $\$$

F. EXPECTED PROFIT:

Sale wt.

Gross return

(F) $\$$ 1bs. $\mathbf{x}$ expected sale price $\$$ - Total expenses (E) \$
$/ 1 b_{0}=\$$

$=$ per head $\$$

G. BREAK-EVEN SALE PRICE: 


\section{APPENDIX I - GOVERNMENT PUBLICATIONS}

1. A Consensus of Costs and Returns: 200 Head Farm Feedlot, Olds District, March 1980, Alberta Agriculture, Number 202.

2. Economics of Feeding Cattle in South Central and Southern Alberta, August 1980, Alberta Agriculture, Agdex 821-7.

3. Feeder Cattle Selling Prices Required to Cover Costs, Alberta Agriculture, Agdex 420/816-1.

4. Feeder Cattle: What Can You Pay? September 1983, Alberta Agriculture, Adgex 420/816-2.

5. Feeding and Management Guide for Growing Beef Cattle, January 1982. British Columbia Ministry of Agriculture and Food.

6. Feedlot Management, 1983. Manitoba Agriculture.

7. Feedlot Management, Information for Decision Making and Control, February 1981. Alberta Agriculture.

8. How to Formulate Rations for Beef Cattle, 1980. Alberta Agriculture, Agdex 420/52-1.

9. Potential Areas for Increasing Beef Cattle Feeding Efficiency in Western Canada by 1990, November 1979. Alberta Agriculture, Agdex 420-079.

10. The Weekly Livestock Market Review, Alberta Agriculture. 


\section{APPENDIX \| - QUESTIONS? PLEASE CALL US}

REGIONAL LIVESTOCK SPECIALISTS AND FARM ECONOMISTS

1. Lethbridge Regional

Agriculture Centre

Lethbridge, Alberta

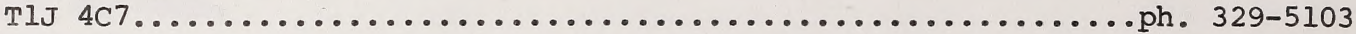

2. Airdrie Regional

Agriculture Centre

Bag Service \#l

Airdrie, Alberta

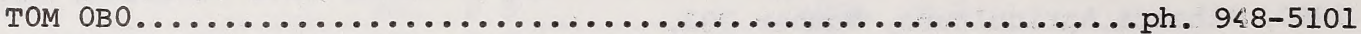

948-5101

3. Red Deer Regional

Provincial Building

3rd Floor, 4920 - 51. Street

Red Deer, Alberta

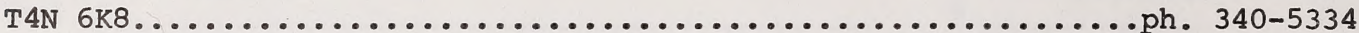

$340-5358$

4. Vermilion Regional

Provincial Building

P.O. Box 330

Vermilion, Alberta

TOB 4MO

ph. 853-2811

853-5381

5. Barrhead Regional

Provincial Building

Box 1540

Barrhead, Alberta

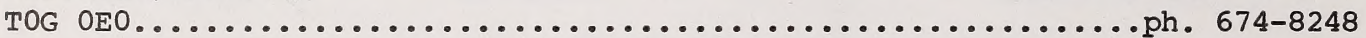

674-3351

6. Fairview Regional Office

Provincial Building

Box 7777

Fairview, Alberta

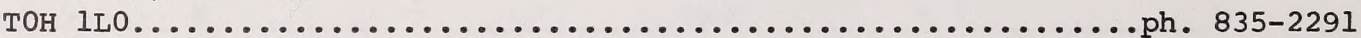

$835-2291$

FARM BUSINESS MANAGEMENT BRANCH

7. Farm Business Management Branch

Box 2000

Olds, Alberta

TOM IPO

.ph. 556-4240 



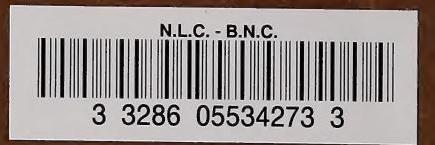

